\title{
Energy Service Companies as a Component of a Comprehensive University Sustainability Strategy
}

\author{
Joshua M. Pearce ${ }^{1}$ and Laura L. Miller ${ }^{2}$
}

\begin{abstract}
The sustainability deficit observed in modern universities is not necessary to fulfill the education, research, or administrative functions of the university system, because a vast quantity of natural resources are currently wasted. The current waste thus provides a large number of opportunities to improve environmental stewardship while reducing operating costs. Guaranteed energy savings programs (GESPs), which utilize the technical and financial expertise of energy service companies (ESCOs), provide a means to capitalize on these opportunities to move universities towards sustainability. The guaranteed savings from energy conservation measures provide more than sufficient funds to service loan payments each year for the capital needed to make efficiency improvements and generally completely pay for themselves in ten years or less. Energy savings projects are win-win situations, addressing both ecological and economic stewardship. The utilization of ESCOs can accelerate the implementation of energy savings projects and garner institutional support for sustainability initiatives. This paper focuses on the best practices of a comprehensive Environmental Stewardship Strategy that includes a GESP to expand a university's environmental stewardship. The GESP improved the operational efficiency, decreased the ecological footprint, and reduced the operating costs of the University. The environmental and economic benefits and limitations of this approach will be critically analyzed in the context of sustainability with the goal of providing a model for other universities to improve upon.
\end{abstract}

Keywords: energy service company, ESCO, energy service performance contracting, guaranteed savings, service contract, sustainability

\section{Bionotes:}

Joshua Pearce was the Mueller Project Coordinator for the Penn State Green Destiny Council. He is currently an assistant professor of physics at the Clarion University of Pennsylvania where he researches applied sustainability and the physics of solar photovoltaic devices and materials.

Laura Miller is an Energy Program Engineer at the Office of the Physical Plant at the Pennsylvania State University where she oversees the Guaranteed Energy Savings Program. She is a registered Professional Engineer in Pennsylvania and holds the Certified Energy Manager’s registration.

1. Clarion University of Pennsylvania

2. The Pennsylvania State University

Corresponding Author:

Joshua M. Pearce

Assistant Professor of Physics

Clarion University of Pennsylvania

106 Peirce Science Center

Clarion, PA 16214-1232

Phone: 814-393-2713 
Published in: Joshua M. Pearce and Laura L. Miller, "Energy Service Companies as a Component of a Comprehensive University Sustainability Strategy”, International Journal of Sustainability in Higher Education, 7(1), pp. 16-33, 2006. http://dx.doi.org/10.1108/14676370610639227

Fax: 814-393-1630

Email: jpearce@clarion.edu 
Published in: Joshua M. Pearce and Laura L. Miller, "Energy Service Companies as a Component of a Comprehensive University Sustainability Strategy”, International Journal of Sustainability in Higher Education, 7(1), pp. 16-33, 2006. http://dx.doi.org/10.1108/14676370610639227

\section{Introduction}

The negative social, health, and ecological impacts of society's current unsustainable patterns of resource exploitation and waste disposal are now well documented. The magnitude and severity of the implications of this global environmental disruption have led many to believe that humankind faces a "sustainability crisis" in which we are approaching the "ecological threshold" and the "limits of the natural system" of the planet (Goodland, et al., 1991; Meadows et al., 1992; Orr, 1992; Postel, 1994; Rees, 1996). In order to take a precautionary approach to prevent irreversible damage to the life support system of the earth, we must overcome the key challenge of the $21^{\text {st }}$ century: move (probably) 11 billion people through the transition complex to a sustainable state (Harper, 2000). As institutions with significant access to the latest knowledge of both ecological problems and socio-techo solutions, universities have both the opportunity and the responsibility to meet this challenge and lead society towards sustainability (Uhl and Anderson, 2001). Many universities have begun to answer this challenge by taking positive steps on the path to sustainability, and a growing number of these universities are creating comprehensive strategies to improve their environmental stewardship (Sharp, 2002). This paper will focus on the best practices at The Pennsylvania State University (Penn State), which has begun to act on its responsibility to implement sustainability in its campus operations through a process described in detail previously (Pearce and Uhl, 2002). The comprehensive scope of Penn State's environmental efforts is seen in Table 1, which summarizes the Environmental Stewardship Strategy (ESS).

\begin{tabular}{|c|c|}
\hline Area & Summary of Policy \\
\hline 1. Purchasing & $\begin{array}{l}\text { Demonstrate a commitment to environmental responsibility through } \\
\text { encouraging purchasing choices to help create and sustain markets for } \\
\text { environmentally responsible and recycled content products. }\end{array}$ \\
\hline 2. Conserve Energy and Water & $\begin{array}{l}\text { Demonstrate a commitment to minimizing the consumption of energy } \\
\text { and water by promoting efficient use and improving energy and water } \\
\text { performance in facilities and operations. }\end{array}$ \\
\hline 3. Minimize Solid Waste & $\begin{array}{l}\text { Continue and enhance processes that minimize solid waste generation } \\
\text { through reduction, reuse and recycling. }\end{array}$ \\
\hline $\begin{array}{l}\text { 4. Minimize Toxic Material } \\
\text { Use and Hazardous Waste }\end{array}$ & $\begin{array}{l}\text { Develop and maintain efficient use, tracking, storage, and disposal of } \\
\text { hazardous and toxic materials. }\end{array}$ \\
\hline 5. Planning and Design & $\begin{array}{l}\text { Consider environmental implications in the development, construction, } \\
\text { and operation of campus infrastructure, grounds, and buildings. }\end{array}$ \\
\hline 6. Transportation & $\begin{array}{l}\text { Facilitate pedestrian travel, bicycle use, and other modes of } \\
\text { transportation that minimize environmental impact. }\end{array}$ \\
\hline 7. Regulatory Compliance & $\begin{array}{l}\text { Ensure that facilities and practices meet or exceed compliance with all } \\
\text { applicable State and Federal environmental regulations. }\end{array}$ \\
\hline 8. Leadership and Education & $\begin{array}{l}\text { Provide leadership for environmental stewardship through education } \\
\text { and example. }\end{array}$ \\
\hline
\end{tabular}

Specifically, this paper will provide an overview of a Guaranteed Energy Savings Program (GESP) that utilized an energy service company (ESCO) to expand the environmental stewardship of the University. The GESP improved the operational efficiency, decreased the ecological footprint, and reduced the operating costs of the University. The environmental and economic benefits and limitations of this approach will be critically analyzed in the context of sustainability with the goal of providing a model for other universities to improve upon. 
Published in: Joshua M. Pearce and Laura L. Miller, “Energy Service Companies as a Component of a Comprehensive University Sustainability Strategy”, International Journal of Sustainability in Higher Education, 7(1), pp. 16-33, 2006. http://dx.doi.org/10.1108/14676370610639227

\section{The Problem: The University Sustainability Challenge}

Although Penn State has formally committed to acting as a role model of sustainability for the rest of society, the University's ecological footprint continues to increase because of both energy intensity and gross square feet. In the last few years, 2 million gross square feet have been added to accommodate the new college of Information Science and Technology, updated laboratory space for many of the sciences and engineering functions, the business college, new modernized residence living quarters, parking facilities, and a chilled water plant. This negative ecological impact is increasing despite the considerable dedication and hard work of administration, faculty, staff and students to improve environmental stewardship over the last several years. This sustainability gap was meticulously documented by the Penn State Green Destiny Council (PSU GDC) ${ }^{2}$ in two Sustainability Indicators Reports $(1998,2000)$. The real width of the sustainability gap was made even clearer in a student written and researched study (The Mueller Report) of a single campus building, the Mueller Building on the University Park campus (Pearce and Russill, 2003). The Mueller building is roughly average in terms of resource use per unit area $\left(216,155 \mathrm{BTU} / \mathrm{ft}^{2}\right)$ at Penn State, where there are 1,642 buildings (Donovan, 1999). The building consumes 2,872,210 kW-hrs of electricity and an additional 2,564,019 kW-hrs equivalent in heating energy each year (PSU GDC, 2001). This energy consumption is linked to the combustion of 2,223 tons of coal, the burning of which releases over 5,750 tons of carbon dioxide (PSU GDC, 2001). Following the ecological footprint model, developed by Wackernagel and Rees, a building's aggregate ecological footprint is a measure of the productive land area needed to support all the material input and disposal needs of that building in a sustainable way (1995). Considering only the coal consumed to provide electricity in the one building for a single year, the need for a radical shift in operating principles to reach a sustainable state becomes obvious. The coal, a highly compacted plant biomass, is the result of past photosynthesis. If the Mueller Building relied not on fossil biomass, a non-sustainable resource, but, instead, on present-day photosynthesis (i.e. renewable biomass), the building would require a 255 acre biomass energy plantation to supply just its electricity needs (PSU GDC, 2001). The analysis of the Mueller Building revealed that it is, indeed, possible to simultaneously reduce an average academic building's aggregate environmental impact in many areas while saving significant quantities of money. By following the energy conservation measures (ECMs) outlined in the energy sections of the Mueller Report, the building could reap more than \$45,000 per year in energy savings alone (PSU GDC, 2001). Most campus buildings, both at Penn State and at other universities, suffer from the same inefficiencies.

The operating status quo at many universities fails to capitalize on the enviro-economic opportunities primarily because of the following factors: i) relative invisibility of operations for decision makers, ii) deferred maintenance backlogs, iii) lack of initial capital/labor, and iv) sub-optimal behavior of building occupants.

First, the physical operations of the university are relatively 'invisible' to top university decision makers and are thus a low priority. The energy costs, although considerable, are dwarfed by other costs in the operating budget (e.g. salaries and healthcare). For example at Penn State, electricity costs are approximately one million dollars per month, but the total operating budget is over \$2.5 billion with over \$1.1 billion in the general funds budget (The Pennsylvania State University Budget Office, 2004). In addition, unless the benefits of energy conservation are documented and publicized, they are easily overshadowed by increased consumption due to new construction and new electronic devices. Finally, 
Published in: Joshua M. Pearce and Laura L. Miller, "Energy Service Companies as a Component of a Comprehensive University Sustainability Strategy”, International Journal of Sustainability in Higher Education, 7(1), pp. 16-33, 2006. http://dx.doi.org/10.1108/14676370610639227

donations to the university are often "ego-driven", which discriminates against operating features of the budget ${ }^{3}$.

Second, because routine maintenance can often be postponed without immediate visible negative consequences, it is one of the first budget items eliminated in times of tight budgets or deferred to future budget cycles. Even with budget surpluses, it is extremely tempting to university leaders to invest in new construction rather than maintaining current buildings for the reasons discussed above. Continued disregard of routine maintenance can lead to considerable backlogs. The Association of Higher Education Facilities Officers, the National Association of College and University Business Officers, and Sallie Mae surveyed 400 colleges and universities and found that American higher education has at least a \$26 billion backlog of deferred maintenance, with the worst deferred maintenance problems concentrated at the research and doctoral universities (Kaiser, 1996). This accumulated deferred maintenance can represent a substantial portion of university budgets. For example, the estimated capital renewal needs for the next fifteen years at Penn State's University Park Campus alone, are \$1 billion. The Penn State Office of Physical Plant (OPP) staff is stretched thin to put out maintenance "fires" as the work continues to pile up. This operating regime is extremely inefficient, because many systems use unnecessary energy when not cared for properly (e.g. failed steam traps, dirty condenser coils, clogged pipes in the chilled and hot water delivery systems).

In some cases, life cycle cost (LCC) analysis are not considered at all in university decision making because of a concentration on short term profit at the expense of long-term sustainability (both economic and ecological). However, large maintenance backlogs also force knowledgeable university administrators to abandon correct economics by disregarding labor costs in LCC analysis. For example, Penn State does not include labor savings in any life cycle calculations, because no employee positions will be lost because of the large deferred maintenance backlog - the given "saved labor" of an OPP worker would simply move onto another project in a long list. However, the labor costs represent an enormous percentage of potential savings, and by excluding labor cost considerations many extremely good economic investments are missed, and current energy losses are aggravated by inefficient equipment. Avoided material costs are also not included in the LCC analysis. If the material and labor costs are included, it would approximately double the economic benefit, or cut the payback period in half. To compensate for such omitted calculations, Penn State recently changed the criterion from a project with a 5-year payback to accept the Commonwealth's recommendation of 10-year payback, as the basis for economic acceptance. On July 15, 2004, Pennsylvania Governor Rendell signed HOUSE BILL 1996, to extend this period to 15 years, however, Penn State will remain at a 10-year payback. It should be pointed out here that this remains an extremely conservative payback time goal -- equivalent to a $10 \%$ internal rate of return on technologies with long lifetimes.

A third reason for the lack of exploitation of enviro-economically beneficial opportunities is there may not be enough capital at a university to take advantage of long-term economically beneficial energy conservation measures (ECMs). Many ECMs such as window replacements require considerable pay back times. Universities can often economically justify such long pay back times by considering the lifetime of a device or system and translating the payback time into an investment rate of return to compare to the university's strictly financial investments (Pearce and Uhl, 2003). However, many universities simply do not have access to the needed initial capital. Similarly, universities with limited personnel resources may not have the labor necessary to complete all the ECMs for which they are knowledgeable. Sometimes when capital is available through major maintenance funds or capital improvement funds, the ability to transfer money across budgets does not exist. Careful pre-planning and cooperation amongst facilities managers is important for identifying funds to buy down projects to acceptable payback periods/rates of return. 
Published in: Joshua M. Pearce and Laura L. Miller, "Energy Service Companies as a Component of a Comprehensive University Sustainability Strategy”, International Journal of Sustainability in Higher Education, 7(1), pp. 16-33, 2006. http://dx.doi.org/10.1108/14676370610639227

Finally, an entire class of enviro-economic opportunities are created by sub-optimal behavior of building occupants (e.g. contamination of recycling containers, leaving lights and computers powered on in unoccupied rooms). This, in part, can be ascribed to general ignorance and a low public understanding of operations or infrastructure technologies. However, counter productive behavior can also surface from bitterness towards the university itself (e.g. large percentage cut in grants with little visible benefits (faculty), excessive tuition increases (students), or perceived general exploitation (staff)). In addition, staff responsible for upkeep do not generally work in the buildings, this results in temporal and observational challenges (e.g. malfunctioning heat/a.c. in a classroom is not reported). The largest behavioral-related problem, however, revolves around financial incentives. Building users do not pay energy bills directly and thus do not have a direct financial incentive to conserve. Levy and Dilwali presented a method for universities to partially correct this flaw by providing financial incentives to conserve energy and water (2000), however lack of internal capacity or knowledge of conservation options limited its effectiveness.

\section{The Solution : Market Based Environmental Stewardship Utilizing Energy Service Companies}

Guaranteed energy savings contracting (also known as energy performance contracting) is a practical solution to the four factors limiting a university's ability to capitalize on enviro-economic opportunities. Guaranteed energy saving contracts are offered by energy service companies (ESCOs), which guarantee that the energy and cost savings produced by the comprehensive capital energy project will cover all the costs associated with implementing the project (Donahue, 2003). An ESCO's services include: i) developing, designing, and (sometimes) financing energy efficiency projects; ii) installing and maintaining the energy efficient equipment involved; iii) measuring, monitoring, and verifying the project's energy savings; and iv) assuming the risk that the project will save the amount of energy guaranteed ${ }^{4}$. These services are bundled into the project's cost and are repaid through the economic savings generated. Soft costs such as maintenance and training can also be included in performance contracts if they meet the time requirements for the return on the initial investments. ESCO projects are generally comprehensive, and thus provide an excellent match to a university's environmental stewardship goals. Because ESCOs are considering the university's entire energy use, they often package short payback period ECMs with longer payback ECMs in order to maximize the conservation opportunities (and thus their own profit) while ensuring they are under the goal payback period for the entire project. It is common to use "low-hanging fruit" ECMs (e.g. lighting retrofits with 2 - 5 year paybacks) to "subsidize" longer term retrofits like boilers (20-30 years), or unique ECMs that address the facility needs, but often have longer life cycle returns. ECMs provided by ESCOs include: high efficiency lighting, high efficiency heating and air conditioning, efficient motors and variable speed drives, insulation and weather proofing, new water heaters, piping and steam traps, pumps and priming systems, motion sensors, cooling towers, water conservation, and centralized energy management systems. Generally, the comprehensive energy efficiency retrofits inherent in ESCO projects require a large initial capital investment (on the order of $\$ 1$ million) and offer a relatively long payback period (7 to 10 years). The university's debt payments are tied to the economic savings offered, through the avoided energy, water or sewer costs under the project. The university incurs a debt service payment for the capital improvement, but avoids an equal (or higher) utility bill. The effect to the bottom line of the budget is zero dollars (or net positive if the avoided cost is higher than the debt service payment.) An ESCO's compensation is directly connected to the amount of energy that is actually saved, and not the economic value of that energy. This is an important aspect of modern energy service contracting that greatly reduces fraud. ESCOs assume the technical and performance risk associated with the project and thus greatly reduce the financial risks for the university. 
Published in: Joshua M. Pearce and Laura L. Miller, "Energy Service Companies as a Component of a Comprehensive University Sustainability Strategy”, International Journal of Sustainability in Higher Education, 7(1), pp. 16-33, 2006. http://dx.doi.org/10.1108/14676370610639227

Use of an energy service company hence provides several advantages for universities over selffinancing ECMs: i) no upfront capital is necessary, ii) the ESCO provides superior technical experience, and iii) symbiotic financial incentives to maximize energy conservation and sustainability.

First, the university needs no upfront capital. This single major obstacle of upfront capital limits large-scale sustainability efforts at many universities. ESCO projects, at the very least, are revenue neutral because energy cost savings are used to pay for the necessary capital energy improvements. In addition, ESCO projects reduce the frequency of repairs and lowers maintenance costs associated with inadequate, aging, or outdated equipment (Donahue, 2003).

Second, the ESCO provides the experience and technical knowledge needed to bring a university's operations up to the state-of-the-art. University facilities in general are understaffed and do not have time or the personnel to research ECMs and implement them in all available situations. The ESCOs can also provide up-to-date technical training for building managers and facilities staff. The communication of this specialized knowledge is a key success factor to project development that is often ignored. The educational or awareness component of an energy conservation program removes the elements of surprise, suspicion and fear while creating a sense of participation and contribution that is necessary to achieve the sustainable elements of a program (Ronsivalli, 2002). In addition, the decreased operating costs and superior facilities provided by a GESP can help reduce sub-optimal occupant behavior by i) eliminating human errors with automation of facilities (e.g occupancy sensors to turn off lights or enabling Energy Star features on computer equipment); ii) improving the quality of the built environment and thus reducing occupant dissatisfaction; and iii) eliminating absences and health issues due to indoor air quality (IAQ) issues that often exist in older buildings.

Most importantly, there is a built-in financial incentive for ESCOs to maximize energy conservation measures. This is not true for the units of most universities, where those paying for development and renovation are not responsible for the costs of operating and maintaining such development. In addition, the status quo organizational structure at many universities forces university leaders to make decisions that are not in the best long-term economic or environmental interests of the entire university community (Pearce and Uhl, 2003). Conversely, ESCOs inherently optimize a building system to minimize total cost (initial + maintenance and operation) in contrast to the status quo of most university decisions, which only optimize initial costs. ESCOs also have a financial incentive to implement long-term maintenance in order to guarantee their own profit, because the ESCO is liable for any shortfalls in equipment performance.

There are limitations linked to performance contracting and ESCOs. Although performance contracts are written to provide guarantees with ESCOs taking on much of the risk, many universities are skeptical about the projects. Current ESCOs provide cradle to grave design, engineering, and management of each project and provide written guarantees for the equipment and savings. In older ESCO models during the 1980s the guarantees were not as structured and the measurement and verification pieces were often weak or lacking entirely. To overcome such limitations an organization needs careful planning, a credible ESCO, and a good solid understanding of its facilities and energy needs.

University personnel often believe that their in-house facilities staff can provide the same service therefore reaping all the savings. However, it is often the case that the maintenance and facility staffs are barely managing to keep up with the daily tasks as the backlog of deferred maintenance grows. Universities do not have the time, or expertise to develop and manage such projects to the extent that ESCOs generally do. An ESCO provides expertise based on the latest technologies, and employs engineers whose strengths are energy and the environment. At the same time, as discussed above, ESCOs enjoy an intrinsic financial incentive to maximize the amount of ECMs implemented. By 
Published in: Joshua M. Pearce and Laura L. Miller, "Energy Service Companies as a Component of a Comprehensive University Sustainability Strategy", International Journal of Sustainability in Higher Education, 7(1), pp. 16-33, 2006. http://dx.doi.org/10.1108/14676370610639227

packaging ECMs into an investment grade audit, the ESCO can simultaneously satisfy the facility managers, design engineers, environmental stewards, and financial officers.

\section{Our Experience: The Penn State Guaranteed Energy Savings Program}

In order to capitalize on the advantages offered by performance contracting, Penn State started a Guaranteed Energy Savings Program (GESP) ${ }^{5}$ as part of its comprehensive Environmental Stewardship Strategy (ESS). The GESP was the most significant step of the ESS towards implementing both sound environmental and economic stewardship at Penn State and garnered support from all sectors of the University. The Penn State GESP mimicked the procedures established by the Commonwealth of Pennsylvania, under the Procurement Code, Act 57 (Pennsylvania Department of General Services, 1998). The program utilized a State-qualified ESCO, which provided turnkey, design - bid - build services for self-funded energy savings projects. A key to making the GESP work was for the state to allow the university to enter into multiyear contracts. (Kozlowski, 2004). The project was managed through The Office of the Physical Plant (OPP) and funded through the Office of Finance and Business.

Initially OPP engineers ranked the University Park buildings by highest energy consumption based on BTU/ft ${ }^{2}$. Second, other capital and maintenance programs, along with the University Master plan, were reviewed to eliminate the possibility of renovating the same building twice. Coordination between the programs also provided avenues for additional funding if necessary, by combining targeted building renovations with energy retrofits. OPP staff selected several buildings with the potential to reduce energy consumption through retrofits including: equipment replacement, reprogramming or upgrading control systems, or identifying alternative energy sources. Once selected, building descriptions and energy saving opportunities were created and distributed to a list of selected ESCOs. Nine ESCOs replied with Letters of Interest, from which three were selected to respond to a Request for Proposal. From the three proposals, one ESCO was selected to perform an Investment Grade Audit. Penn State chose to implement ECMs in half of the originally selected buildings to meet the program's defined 10-year payback period.

The current GESP project is in the process of improving the efficiency of 15 buildings at the University Park Campus. The project has been broken into two phases with a contracted cost slightly over \$7 million. In addition, another \$2 million of major maintenance has been included into the project and separately funded. The entire project is being financed with a $4.36 \%$ interest loan. The guaranteed savings from energy and water conservation under the GESP will provide more than sufficient funds to service the loan payments each year and will completely pay for themselves in ten years. Material costs and maintenance are not calculated into the repayment, but would significantly reduce the payback to between $5-7$ years. Many of the ECMs have effective technical lifetimes much longer than 10 years, which means Penn State will garner additional profit from the GESP after the program has officially ended. Penn State thus benefits from buildings that are more efficient, new equipment, better services (e.g. higher quality lighting, heating and air conditioning), and a decreased ecological footprint while enjoying substantial economic savings.

\subsection{Financing}

Penn State is self-funding the first GESP project, rather than using the more traditional thirdparty or ESCO financing. Penn State chose to self-finance primarily to ease the administration burden of using a new construction project process. By adopting the Commonwealth's established processes, Penn State stepped outside its standard procedures of securing funding, and hiring separate firms for the professional and contractor portions of construction projects. Using an ESCO to cover all aspects of the energy projects meant developing a new process that did not fit the current methods. All of the paperwork and procedures for GESP were created, and then accepted by several of the departments 
Published in: Joshua M. Pearce and Laura L. Miller, "Energy Service Companies as a Component of a Comprehensive University Sustainability Strategy", International Journal of Sustainability in Higher Education, 7(1), pp. 16-33, 2006.

http://dx.doi.org/10.1108/14676370610639227

within OPP, the Office of Finance and Business, Risk Management and the contract attorneys. By entering into the third party financing and lease agreement as recommended under Act 57, Penn State would be embarking on yet another uncharted path. At the end of each year, the utility budget at OPP will be reduced by the actual calculated annual savings measured from the "commencement date" of the project until the debt service has been paid in full.

Originally, the idea surrounding a GESP project was to fund a \$2 million project every year for five years. This would allow the $\$ 2$ million to recycle itself by year 6 and the cycle would allow continuous cash flow for financing future projects. Because it took almost an entire year to develop the project and processes, OPP took advantage of 2 years worth of the budget and bid out the project at $\$ 4$ million. The process revealed attractive proposals with price tags around $\$ 5$ million, and the Vice President of Finance and Business and the Controller agreed to increase project funding to match the opportunity.

Funding was further increased to $\$ 9$ million to include ECMs to address energy savings in the steam distribution system and to coincidently perform maintenance that would leave a building in better overall condition than when the project began. The Vice President of Finance and Business coined the term "while you are at it" to describe this concept. The "while you are at it" concept addresses any of the other problems such as maintenance issues or aesthetics. A good example of this involves issues where older buildings must be brought up to current indoor air quality codes. These maintenance issues must be addressed even when little or no energy is saved and sometimes energy use may increase (e.g re-opening outside air dampers that had been permanently sealed shut or installing ductwork in laboratories to isolate and exhaust contaminants). Another example is the "town and gown" issues associated with the aesthetics of the steam plant, located on a downtown main street. Addressing the aesthetic issues added costs to the construction of the protective coal pile structure. The neighbors and Borough Council were extremely supportive of that particular initiative, because it addressed long time concerns of the unsightly and embarrassing coal pile and the associated dust and noise problems generated for the small rural community surrounding the University. The last piece of the project funding had to include some incidentals: replacing of landscaping damaged during construction, assistance from OPP technical crews, and various other tasks that needed to be completed but did not directly save energy. Although by including maintenance, material, and labor savings into the LCC analysis the non-energy costs could be recovered in the $\sim 10$ year time frame, Penn State separately funded the non-energy measures out of maintenance and capital budgets. The bottom line is that energy savings funded energy retrofits which led to avoided energy use and pollution. The benefits of removed pollutants, better lighting, less maintenance, improved comfort, become just that - benefits. They are not falsely measured or calculated or counted - just enjoyed. The improvements to physical assets are funded as they would be under normal maintenance procedures, only pushed ahead of schedule to coincide with energy improvements under the GESP.

\subsection{Overcoming Challenges}

Penn State had to overcome several challenges to successfully implement the energy savings program. The GESP process was developed as a separate process from current design/construction practices established at the university. Before a project proposal could be solicited, new procedures had to be defined and approved. Penn State had practices in place that allowed for the hiring of a Design Professional or Construction Contractor, but nothing for a "contractor" that performed all services combined, as with ESCOs. The closest fit to performance contracting would have been Design-Build contracts, but Penn State also had no projects or procedures in place for that. During the first six months, OPP staff focused on establishing a performance contracting procedure. Opting to modify the Commonwealth's documents took preference over producing new Penn State documents, but created an 
Published in: Joshua M. Pearce and Laura L. Miller, "Energy Service Companies as a Component of a Comprehensive University Sustainability Strategy”, International Journal of Sustainability in Higher Education, 7(1), pp. 16-33, 2006. http://dx.doi.org/10.1108/14676370610639227

administrative burden on the contracting and risk management departments. The use and acceptance of different contracts and agreements still presents an impediment to the standard practice, and often causes delays in the processing of approvals and requests.

Coordination of the many units affected by the GESP was another important challenge. Each building at the university falls into an assigned maintenance area, and each College within the University assigns facility coordinators to those buildings used by that College. Synchronization between the area supervisors and the College's facility coordinators was imperative for the success of the project. The ESCO interviewed the maintenance and facility staff, and when possible included building occupants to develop the best energy plan for each of the selected buildings. Several of the buildings housed general-purpose classrooms. In addition, the use of such classrooms are scheduled through a single classroom coordinator, who needed 12 months advance notice before classroom renovations, regardless of scope, could occur. Coordination efforts at the building level did not include campus-wide initiatives. The largest coordination effort concerned synchronization with the University's other facilities programs including Continuous Commissioning, Major Maintenance, the Capital Plan, and the Renovations Crew. The Continuous Commissioning program included 4-5 buildings per year targeted for in-house energy retrofits and maintenance tune-ups. The Major Maintenance program ranked most buildings through a numerical system of needs to determine a hierarchal order of repair. The Capital Plan looks ahead to determine the future of a total building, and the Renovations Crew responds to more-immediate requests to modify classrooms, offices and other spaces to meet ongoing academic needs. The final selection of buildings for the GESP project relied on the consolidated effort of the building and personnel from all of these programs.

Once building selection was completed, the scope of work needed to be addressed. Working with in-house programs meant exercising caution to avoid the age-old argument that bidding work to outside contractors is taking work away from university employees. Union supervisors assisted with employee meetings to ease some of the concerns amongst the crews. The ESCO often needed assistance from the technical crews for HVAC and electrical issues. The crews supported the requests and often accompanied the ESCO on the building audits and provided key information on systems operations and potential energy conservation opportunities. University electricians opened electrical panels; while University heat and ventilation technicians performed some of the testing and balancing, and escorted contractors through the mechanical rooms. The union also played a key role in supporting the GESP program by working with the ESCO and providing background information on the equipment that they had installed and maintained. The technical staff provided input and concurrence on selected materials such as valves, steam traps, ballasts and other retrofits. The janitorial staff received training on the new lighting systems to overcome some of the relamping and ballast change out issues.

The largest challenge was overcoming extremely low utility rates. OPP manages and provides the utilities of steam, water, and wastewater treatment for the campus. Energy savings calculations based on billable rates would not reflect true savings to the University. Operations costs are removed from the rates for calculation purposes, leaving only the truly avoidable costs to determine life cycle costs. Reducing the amount of water or steam used, will not significantly reduce costs associated with campus facilities. Nor will there be any effect on the number of employees required to maintain the plants or distributions systems. As an example, the avoidable costs for water are the electricity to pump the water and the chemicals used to treat the water -- leaving the combined avoidable water/wastewater cost at less than fifty cents per 1000 gallons. To hinder favorable LCC calculations further, provider rates are low at the University Park campus with electric rates less than 3 cents per $\mathrm{kW}$-hr and a demand charge lower than $\$ 8$ per $\mathrm{kVA}$. In addition, when conditions are favorable, oil procurement takes place during the off-season because of storage capability, and natural gas contracts are shopped on the open 
Published in: Joshua M. Pearce and Laura L. Miller, "Energy Service Companies as a Component of a Comprehensive University Sustainability Strategy", International Journal of Sustainability in Higher Education, 7(1), pp. 16-33, 2006. http://dx.doi.org/10.1108/14676370610639227

market for competitive pricing. Remarkably, many of the current systems on the campus were so inefficient that economically justifiable ECMs could be deployed despite these low utility rates.

\subsection{Energy Conservation Measures}

The ECMs for Penn State's first project range from the traditional lighting to the unique retrofits and construction at the university's steam plant:

- $\quad$ Lighting retrofits in 15 buildings including 31,000 lamps, 12,000 ballasts, and 2000 fixtures;

- Water retrofits in 3 residential housing buildings including 132 water closets, 13 urinal retrofits, 122 showerheads, and 104 faucets;

- $\quad$ Steam management in one residence hall including 400 steam trap replacements;

- $\quad$ Energy and maintenance tune-ups in 15 buildings including repair of existing systems and tune up to the original design intent (or modification to meet current system needs);

- $\quad$ HVAC Tune-ups including connections to campus chilled water system and replacement of two 25 year old chillers with new efficient process chillers;

- $\quad$ Replacement of pneumatic systems with new direct digital controls (DDC);

- $\quad$ Steam plant upgrades including the construction of a structure to protect coal from rainwater and snow, installation of a new reverse osmosis system in West Campus Steam Plant and transferring the existing electronic dialysis water treatment to the East Campus Steam Plant.

Phase 1 of the project centered on lighting, plumbing, and the steam trap replacements in order to have the work performed when the student population was at a minimum during the summer months. The ECMs were performed in the residence halls and classrooms and would have interrupted student life if construction took place during the peak fall or spring semesters. Lighting retrofits in the project reduced consumption and increased the amount of light output. One very common fluorescent system is a 2' $\mathrm{x}$ 4' fixture that fits in the drop ceiling panels. The standard fixtures have four 32W lamps and two ballasts that nominally accounts for $140 \mathrm{~W}-160 \mathrm{~W}$. In some instances, facility personnel had already delamped, or removed, two of the fluorescent tubes for a system operating at approximately 80W. The new systems used a 2-lamp/single ballast combination that consumes 48W. In addition, the new lamps have rated lives of 30,000 hours as compared to the existing lamps that ranged from 10,000 to 20,000 hours. As an additional bonus, OPP was able to establish a relamping program in all of the retrofit buildings that improved performance while driving down labor costs. Similar calculations and measurements were performed for the water and plumbing retrofits. As an example, older water closets that vary from 4-6 gallons per flush were replaced with newer technology flush valves and china where consumption was reduced to 1.5 gallons per flush. The last set of ECMs in Phase 1 occurred unexpectedly when a building shut down was scheduled in one of the residence halls. Most of the 400 steam traps, which control for steam flow into the student rooms, hallways, and steam equipment, in the building had failed and needed to be replaced. Failure of the devices allows for unmodulated steam flow or no steam flow to the terminal units. Based on the input of the steam trap specialists at OPP, the ESCO was able to choose an economically and environmentally superior solution. The initial cost of the new trap cost three times as much, but is expected to last $5-7$ times as long and solve the constant problem of failed steam traps. In addition, during the steam trap project, an opportunity for asbestos abatement was presented. Considering the removal of mercury fluorescent lamps and the asbestos, Penn State was able to take advantage of hazardous waste disposal in the GESP as an added benefit to the environment. 
Published in: Joshua M. Pearce and Laura L. Miller, “Energy Service Companies as a Component of a Comprehensive University Sustainability Strategy”, International Journal of Sustainability in Higher Education, 7(1), pp. 16-33, 2006. http://dx.doi.org/10.1108/14676370610639227

Phase 2 of the GESP began in June 2004 and includes improving building systems and controls. New DDC systems will allow the Central Control System to monitor buildings and to lower temperatures in winter or raise them in the summer when the buildings are unoccupied. Occupancy sensors and carbon dioxide $\left(\mathrm{CO}_{2}\right)$ monitors are a significant part of the new controls. Occupancy sensors use infrared technology and motion detection to sense temperature and movement in a room. When the sensor indicates no occupants, the lights are diminished. $\mathrm{CO}_{2}$ monitors work in the same way by monitoring exhaled $\mathrm{CO}_{2}$. Air conditioning systems are designed for maximum occupancy. When fewer than the maximum number of occupants are in the room, the fresh air requirements are reduced as is the air conditioning requirements by monitoring $\mathrm{CO}_{2}$ levels. This results in energy savings while meeting IAQ standards. Finally, one building used two antiquated chillers to provide comfort and process cooling. The chilled water from both systems was often needed to maintain building comfort and research requirements. In the GESP project, those chillers will be removed and replaced with two separate systems. Process cooling will be handled by chillers designed specifically for lower temperature chilled water applications, and the comfort cooling will be connected to the campus chilled water system.

One of the unique ECMs in the GESP is the construction of a coal pile structure at the West Campus Steam Plant (WCSP). The design intent of the structure is to protect the coal from rain and snow, because wet coal does not burn efficiently in the boilers. In order to maintain the correct temperature with saturated coal, natural gas had been injected into the boilers to prevent the fire from diminishing and causing a boiler shutdown. It is estimated that this ECM could avoid between $\$ 65,000$ and $\$ 100,000$ per year in natural gas costs. The WCSP will also be provided with a newer more efficient water treatment system, and the existing water treatment system will be recycled to the East Campus Steam Plant, which currently has no water treatment. When raw, or untreated, water is used in boilers, minerals build up inside the boiler. A process known as boiler blowdown flushes out these deposits to aid in preventing internal damage to the boilers and associated components. When blowdown occurs, the heated water is flushed along with the debris. The energy from the discarded water cannot be captured or reused. Treating water reduces the minerals and increases the blowdown intervals, thereby reducing the amount of energy wasted with each flushing of the system.

\section{Results}

Overall Penn State's first ESCO program was extremely successful. Each year the GESP will prevent the emission of the following pollutants: 8,000 tons of carbon dioxide, 18 tons of $\mathrm{NO}_{\mathrm{x}}, 60$ tons of $\mathrm{SO}_{x}, 1,500$ pounds of $\mathrm{CO}, 1,500$ pounds of particulate matter, 200 pounds of volatile organic compounds, and six ounces of mercury. The environmental savings provided by the GESP are thus the highlight of Penn State's Environmental Stewardship Strategy. The GESP was also extremely economically successful as can be seen in Table 2 .

\begin{tabular}{|l|c|c|c|}
\hline Energy Conservation Measure & $\begin{array}{c}\text { Savings per } \\
\text { year }\end{array}$ & Total Cost & $\begin{array}{c}\text { Simple } \\
\text { Payback } \\
\text { (years) }\end{array}$ \\
\hline Lighting & $\$ 127,403$ & $\$ 1,472,633$ & 11.6 \\
\hline Atherton Steam Trap Replacement & $\$ 58,887$ & $\$ 320,148$ & 5.4 \\
\hline Water Conservation & $\$ 44,126$ & $\$ 240,295$ & 5.4 \\
\hline TOTAL PHASE 1 & $\$ 230,416$ & $\$ 2,033,076$ & 8.8 \\
\hline DDC Controls & $\$ 280,419$ & $\$ 2,029,232$ & 7.2 \\
\hline Retro-commissioning & $\$ 146,988$ & $\$ 1,306,563$ & 8.9 \\
\hline Coal Pile Roof & $\$ 66,457$ & $\$ 886,708$ & 13.3 \\
\hline
\end{tabular}


Published in: Joshua M. Pearce and Laura L. Miller, "Energy Service Companies as a Component of a Comprehensive University Sustainability Strategy”, International Journal of Sustainability in Higher Education, 7(1), pp. 16-33, 2006. http://dx.doi.org/10.1108/14676370610639227

\begin{tabular}{|c|c|c|c|}
\hline RO System & $\$ 68,685$ & $\$ 613,320$ & 8.9 \\
\hline Noll Lab & $\$ 63,173$ & $\$ 677,911$ & 10.7 \\
\hline TOTAL PHASE 2 & $\$ 625,722$ & $\$ 5,513,734$ & 8.8 \\
\hline PROJECT SUMMARY * & $\$ 856,138$ & $\$ 7,546,810$ & 8.8 \\
\hline \multicolumn{4}{|c|}{$\begin{array}{l}\text { Table 2. Economic savings from Phase I and II of the Penn State GESP. } \\
\text { * Note: Does not include } \$ 2,345,343 \text { of separately funded maintenance, } \\
\text { architectural and system improvements that enhanced the project but did not } \\
\text { contribute to energy savings. }\end{array}$} \\
\hline
\end{tabular}

The GESP also assisted in correcting the misconceptions of the general public (Kempton, et al., 1995) and university decision makers - that environmental stewardship is an additional expense. Economic stewards of the university in times of raising tuition often view environmental or sustainability goals as "unrealistic" because of economic constraints. However, those accustomed to watching the bottom line for the university are primed to appreciate the financial opportunities available from energy performance contracting. This is because the energy efficiency measures provided by the ESCO are investments - not expenses or additional costs. These energy savings projects are win-win situations, addressing both economic and ecological goals. Utility costs are reduced through new equipment featuring the latest technology and better efficiencies; along with the associated benefit of improved efficiency is the reduction in the emissions of pollutants into the air, water, and earth. The sustainability investments that garner real economic savings are thus highly prized, and other environmental stewardship initiatives are not automatically dismissed as idealistic fantasies. Investing in energy efficiency can free funds that are now being spent for wasted energy. Energy efficiency, in effect, generates 'revenue' that can be redirected to buying new band uniforms, leasing an MRI, achieving a more competitive edge...or giving yourself a raise (Hansen, 1992). The success of the Penn State GESP helped to solidify the support of the upper administration at Penn State for the ESS (Kozlowsky, 2004). Utilizing ESCOs in the university setting is a useful method to recruit university. administration to environmental stewardship and catalyze the transition of a university towards sustainability.

Other universities have had similar positive experiences with ESCOs. The University of Buffalo completed a comprehensive \$17 million project involving a plethora of ECMs that produced more than $\$ 3$ million in annual savings as well as a $15 \%$ reduction in $\mathrm{SO}_{2}, \mathrm{NO}_{\mathrm{x}}$, and $\mathrm{CO}_{2}$ emissions from campus energy use (Simpson, 2003). Other universities that have successfully utilized ESCOs to decrease their operating costs while moving towards sustainability include: Duquesne University (Donahue, 2003), Baylor University, Florida International University, Eastern Illinois University, Syracuse University, California State University and many others (Eibott, 2001).

Despite the enormous opportunity to implement cost effective measures to reduce the University's environmental footprint the challenge of achieving sustainability on campus remains unmet. The operation of the University consumes vast quantities of energy, the majority of which is derived from carbon-based non-renewable fossil fuels. This energy consumption along with the related greenhouse gas emissions (and thus contributions to global climate destabilization) are increasing University wide. The greenhouse gas emissions increased by $32.4 \%$ from 1990 to 2003 from 336,273 metric tons of $\mathrm{CO}_{2}$ equivalent $\left(\mathrm{MTCO}_{2} \mathrm{E}\right)$ to 445,315 $\mathrm{MTCO}_{2} \mathrm{E}$ (Steuer, 2004). Even with current environmental stewardship measures (including the GESP) taken into account, these emissions are projected to continue to increase by 56.3\% over 1990 levels by 2012 (Steuer, 2004). These numbers are 
Published in: Joshua M. Pearce and Laura L. Miller, "Energy Service Companies as a Component of a Comprehensive University Sustainability Strategy”, International Journal of Sustainability in Higher Education, 7(1), pp. 16-33, 2006. http://dx.doi.org/10.1108/14676370610639227

particularly sobering if viewed in the context of the university system leading society to a sustainable state.

Currently it is clear that energy performance contracting does not meet the rigorous goals of sustainability criteria even if growth is ignored. ESCOs are only useful for meeting modest greenhouse gas emission reduction goals such as the Kyoto Protocol, because they typically guarantee that a facility will achieve $25 \%$ cost savings in utility bills (Eilbott, 2001), which can be roughly equated to a $25 \%$ reduction in green house gas emissions due to energy conservation. It is apparent at this time, that although simple economic arguments aid in the movement towards sustainability, they are not enough. To complete this progression, the payback period used for guaranteed energy programs needs to be extended beyond ten years. This can be done purely in economic terms by including labor and maintenance costs, but there is also a need to quantify the extrinsic benefits of health, learning, environmentally responsible reputation, and productivity in order to expand the number of ECMs that meet payback time criteria at universities. For example, ESCO projects can enhance indoor air quality (IAQ) and building comfort. Asthma, allergic chronic disease, and acute respiratory infections can all be exacerbated by poor IAQ. Non-specific eye, nose, throat, and skin irritation; headache, fatigue, drowsiness; lack of concentration; dizziness; and nausea can also be caused by inadequate IAQ (Birr \& Donahue, 2001). Conversely, improved IAQ results in health benefits such as a 30\% reduction in acute respiratory infections and a 50\% reduction in acute non-specific health symptoms in schools (Bayer, et al., 1999). Staff productivity benefits from improved indoor air quality could easily pay for the cost of school ventilation improvements within three years (Birr \& Donahue, 2001). If only the real benefits of IAQ improvements could be quantified in a reliable way, the resultant extended payback period would have the benefit of assisting truly sustainable technologies such as solar photovoltaics (Pearce, 2001) meet the investment criteria. In this way adoption of a comprehensive set of ECMs for a university could eventually lead to a sustainable campus. Finally, it should be noted that the bar of a purely sustainable university is not high enough. If educational institutions are to be leading the charge for sustainability in society, universities must become restorative - that is, the operation of the university must actively restore the damage done to the environment from past and current human degradation.

\section{Conclusions}

The sustainability deficit of society is mirrored in our colleges and universities. Fortunately, the sustainability deficit is not necessary to fulfill the education, research, or administrative functions of the university system because much of the natural resources used by the university system are currently wasted. Because of this inefficient use of the resources, universities have an incredible number of opportunities to reduce operating costs while improving their environmental stewardship. However, many of these opportunities remain unrealized because of the barriers of operations invisibility, deferred maintenance backlogs, initial capital costs/labor shortages, and sub-optimal occupant behavior. Guaranteed energy savings programs, which utilize the technical and financial services of energy service companies, provide a means to overcome these barriers and move universities towards sustainability. Use of an ESCO provides several advantages for universities over self financing energy conservation measures including: i) no upfront capital is necessary, ii) superior technical experience is available, and iii) the existence of intrinsic financial incentives to maximize energy conservation. The guaranteed savings from energy and water conservation form the ESCO provide more than sufficient funds to service loan payments each year for the capital needed to make the improvements and generally completely pay for themselves in ten years or less. Utilizing ESCOs in the university setting is also a useful method to catalyze university administration to support sustainability initiatives. Energy savings projects are win-win situations, addressing both economy and ecology and the utilization of ESCOs is a method that can be used to accelerate their implementation. 
This paper utilized the Guaranteed Energy Savings Program at Penn State University as an example of the environmental and economic advantages and challenges of utilizing energy performance contracting at the university level. Overall Penn State's first attempt at an ESCO program was extremely economically successful with more than $\$ 7.5$ million to be saved over the next 10 years. In addition, the environmental benefits are staggering with emission reductions of 8,000 tons of carbon dioxide, 18 tons of $\mathrm{NO}_{\mathrm{x}}, 60$ tons of $\mathrm{SO}_{\mathrm{x}}, 1,500$ pounds of $\mathrm{CO}, 1,500$ pounds of particulate matter, 200 pounds of volatile organic compounds, and 6 ounces of mercury each year for the next 10 years. Reducing emissions strengthens Penn State's commitment to environmental stewardship, with the reductions under the GESP as the most substantial concrete demonstration of the University's commitment to their Environmental Stewardship Strategy to date.

\section{Acknowledgements}

The authors would like to acknowledge helpful discussions and collaborations with Ford Stryker, Chris Russill, Paul Ruskin, and Christopher Uhl.

\section{Notes:}

1. For more information on environmental programs catalyzed by the Environmental Stewardship Strategy see Penn State’s “Blue, White and Green” page, Available: http://www.psu.edu/ur/psugreen/

2. The Penn State Green Destiny Council is an association of students, faculty, and staff committed to promoting ecological responsibility at Penn State. The council believes that institutions of higher education can be leverage points in the transition to a sustainable society in so far as they model sustainable practices and foster ecological literacy. For more information http://www.bio.psu.edu/greendestiny/index.shtml

3. Alumni and corporate donors are more likely to contribute money to have buildings constructed and named after them. Paying for steam-trap cleaning or electricity to run the lights in these buildings is considerably less appealing.

4. For more information about ESCOs contact the National Association of Energy Service Companies (NAESCO) at 1615 M Street, N. W. Suite 800, Washington DC, 20036. Phone (202) 822-0950 Fax (202) 822-0955 http://www.naesco.org/

5. For more information on the Penn State GESP see Office of the Physical Plant, ESCO Program, Available: http://energy.opp.psu.edu/engy/ESCO/ 
Published in: Joshua M. Pearce and Laura L. Miller, “Energy Service Companies as a Component of a Comprehensive University Sustainability Strategy”, International Journal of Sustainability in Higher Education, 7(1), pp. 16-33, 2006. http://dx.doi.org/10.1108/14676370610639227

\section{References}

Bayer, C., Crow, S., and Fischer, J. (1999), Causes of Indoor Air Quality Problems in Schools: Survey of Scientific Research, Oak Ridge National Laboratories, Oak Ridge.

Birr, D, and Donahue, P. (2001), "How energy performance contracting can help school provide comfortable, healthy and productive learning environments.” Meeting the Challenge. National Association of Energy Service Companies \& U. S. Environmental Protection Agency, Washington D.C.

Donahue, P. (2003), “Implementing energy efficient retrofits at state agencies and public sector institutions: commonwealth of Pennsylvania” NAESCO State Guidebook Series, National Association of Energy Service Companies, Washington D.C.

Donovan, D. (1999), “University Park Energy Use Per Facility”, The Pennsylvania State University, Office of the Physical Plant, University Park. Available http://energy.opp.psu.edu/engy/Consumpt/UP/Facility/BTUSQFT.htm

Eilbott, E. D. (2001), Reducing operating costs and improving the facility infrastructure: Energy efficient capital upgrades in Colleges and Universities, National Association of Energy Service Companies, Washington D.C.

Goodland, R., Daly H. E. and El Serafy, S. (1991), Environmentally Sustainable Development: Building on Brundtland. The World Bank, Washington DC.

Hansen, S. J., (1992), Performance Contracting for Energy and Environmental Systems, The Fairmont Press, Lilburn.

Harper, P. (2000), “The end in sight? Some speculations on environmental trends in the twenty-first century”, Futures, Vol. 32, pp. 361-384.

Kaiser, H. (1996), A Foundation to Uphold: A study of Facility Conditions at U.S. Colleges and Universities, The Association of Higher Education Facilities Officers, Alexandria.

Kempton, W., Boster, J.S. and Hartley, J. (1995), Environmental values in American culture, MIT Press, Cambridge.

Kozlowsky, D. (2004), “Penn State’s Green Coach”, Building Operating Management, April, pp.28-36.

Levy, J. I., and Dilwali, K. M. (2000), "Economic incentives for sustainable resource consumption at a large University: Past performance and future considerations”, International Journal of Sustainability in Higher Education, Vol. 1 No. 3, pp. 252-266.

Meadows, D. H., Meadows, D. L., and Randers, J. (1992), Beyond the Limits, McClelland \& Stewart Inc., Toronto.

Orr, D. (1992), Ecological Literacy: Education and the Transition to a Postmodern World, State University of New York Press, Albany. 
Published in: Joshua M. Pearce and Laura L. Miller, “Energy Service Companies as a Component of a Comprehensive University Sustainability Strategy”, International Journal of Sustainability in Higher Education, 7(1), pp. 16-33, 2006. http://dx.doi.org/10.1108/14676370610639227

Pearce, J. (2002), “Photovoltaics - A Path to Sustainable Futures”, Futures, Vol. 34 No. 7, pp. 663-674.

Pearce, J. and Uhl, C. (2003), “Getting It Done: Effective Sustainable Policy Implementation at the University Level”, Planning for Higher Education, Vol. 31 no. 3, pp. 53-61.

Pearce J. and Russill, C. (2003), "Student Inquiries Into Neglected Research For A Sustainable Society: Communication and Application”, Bulletin of Science, Technology \& Society, Vol. 23 No. 4, pp.311-320.

Pennsylvania Department of General Services (1998), “Commonwealth Procurement Code - Act 57”, Available http://www.dgs.state.pa.us/dgs/cwp/view.asp?a=3\&Q=113564\&dgsNav=|5053|

The Pennsylvania State University Budget Office (2004), “2003-2004 Budget”, Available http://www.budget.psu.edu/BudgetPresentation/2004-05/income200304.asp

Pennsylvania State University Green Destiny Council (PSU GDC) (1998), The Penn State Indicators Report, Pennsylvania State University Green Destiny Council, University Park.

Pennsylvania State University Green Destiny Council (PSU GDC) (2000), The Penn State Indicators Report 2000: Steps Toward a Sustainable University, Pennsylvania State University Green Destiny Council, University Park. Available http://www.bio.psu.edu/greendestiny/publications/gdcindicators_2000.pdf

Pennsylvania State University Green Destiny Council (PSU GDC) (2001), The Mueller Report: Moving Beyond Sustainability Indicators to Sustainability Action, Pennsylvania State University Green Destiny Council, University Park. Available http://www.bio.psu.edu/greendestiny/publications/gdcmueller_report.pdf

Postel, S. (1994), “Carrying Capacity: Earth’s Bottom Line.” In Brown, Lester R., et al. State of the World, Worldwatch Institute. W.W.Norton, New York.

Rees, W.E. (1996), “Revisiting Carrying Capacity: Area-Based Indicators of Sustainability”, Population and Environment: A Journal of Interdisciplinary Studies, Vol. 17 No. 3, pp. 195-215.

Ronsivalli, L. J. (2002), “The transformation of value-based energy services performance contracting”, Available (Energy Vortex, November) http://www.energyvortex.com/pages/index.cfm?pageid=146

Sharp, L. (2002), “Green Campuses: the road from little victories to systematic transformation”, International Journal of Sustainability in Higher Education, Vol. 3 No. 2, pp. 128-145.

Simpson, W. (2003), "Energy Sustainability and the Green Campus”, Planning for Higher Education, Vol. 31 No. 3, pp. 150-158.

Steuer, C. (2004), “Greenhouse gas emissions from University Park Campus”, Penn State University Masters Thesis - presented at The Pennsylvania State University Environmental Symposium, April. 
Published in: Joshua M. Pearce and Laura L. Miller, "Energy Service Companies as a Component of a Comprehensive University Sustainability Strategy”, International Journal of Sustainability in Higher Education, 7(1), pp. 16-33, 2006. http://dx.doi.org/10.1108/14676370610639227

Uhl, C., and Anderson, A. (2001), “Green Destiny: Universities Leading the Way to a Sustainable Future”, BioScience, Vol. 51, pp. 36-42.

Wackernagel, M. and Rees, W. (1995), Our Ecological Footprint: Reducing Human Impact on the Earth, New Society Publisher, Gabriola Island, BC and Philadelphia, PA. 